\title{
MUTU BAKSO IKAN KAKAP (Lutjanus bitaeniatus) DENGAN PENAMBAHAN BUBUR RUMPUT LAUT (Euchema Cottoni)
}

\author{
Nurbety Tarigan \\ 1)Fakultas Sains dan Teknologi, Program Studi Teknologi Hasil Perikanan, Universitas Kristen Wira \\ Wacana Sumba, JI.R. Suprapto No 35 Waingapu, Telp (0271) 62392, \\ email:nurtarigan@unkriswina.ac.id.
}

\begin{abstract}
Abstrak
Pembuatan dasar bakso ikan selalu menggunakan tepung atau pati sebagai bahan pengikat. Tepung tapioka merupakan salah satu bahan pengikat yang digunakan untuk meningkatkan daya ikat air, akan tetapi mempunyai pengaruh yang kecil terhadap emulsifikasi dalam menghasikan kualitas bakso yang baik. Penambahan bubur rumput laut dalam pembuatan bakso ikan dapat memperbaiki kualitas produk karena sifat fungsional rumput laut sebagai emulsifier. Penggunaan rumput laut sebagai bahan tambahan dalam pembuatan bakso ikan dapat meningkatkan nilai gizi dan kandungan serat pada produk bakso. Penelitian ini bertujuan untuk mengkaji penambahan bubur rumput laut Eucheuma cottoni terhadap mutu bakso ikan kakap dan menentukan konsentrasi penambahan bubur rumput laut terbaik pada bakso ikan kakap. Metode penelitian yang digunakan adalah metode eksperimen dengan 15 panelis dan 4 perlakuan penambahan bubur rumput laut yakni $0 \%, 20 \%, 40 \%, 60 \%$. Parameter yang diamati adalah uji organoleptik (rasa, aroma, dan kekenyalan) dan analisis kimiawi bakso ikan kakap. Hasil penelitian menunjukkan bahwa semua perlakuan bakso ikan dengan penambahan bubur rumput laut masih disukai oleh panelis. Namun, perlakuan penambahan bubur rumput laut sebesar $20 \%$ merupakan perlakuan bakso ikan yang paling disukai oleh panelis dengan skor rasa 6.5 (sangat suka), aroma 7.5 (sangat suka), dan kekenyalan 4.6 (sangat kenyal). Selain itu, penambahan bubur rumput laut sebanyak $20 \%$ menghasilkan kadar air sebesar $74.0 \%$, kadar abu $1.3 \%$, kadar lemak $1.4 \%$, dan kadar protein $12.7 \%$. Bakso ikan kakap dengan penambahan bubur rumput laut telah memenuhi standar SNI 01-7266-2014.
\end{abstract}

Kata kunci: Bakso ikan, E.Cottoni, Organoleptik

\section{Abstract}

The basic manufacture of fish meatballs always uses flour or starch as a binder. Tapioca flour is one of the binders used to increase water binding capacity, but has little effect on emulsification in producing good quality meatballs. The addition of seaweed pulp in the manufacture of fish balls can improve product quality due to the functional properties of seaweed as an emulsifier. The use of seaweed as an additional ingredient in the manufacture of fish balls can increase the nutritional value and fiber content of meatball productsThis study aims to examine the addition of Eucheuma cottoni seaweed porridge to the quality of snapper meatballs and determine the concentration of the addition of the best seaweed porridge to snapper meatballs. This research was conducted at the Integrated Laboratory of the Wira Wacana Christian University, Sumba. The research method used was an experimental method with 15 panelists and 4 treatments adding seaweed porridge ie $0 \%, 20 \%, 40 \%, 60 \%$. The parameters observed were organoleptic tests (taste, aroma, and suppleness) and chemical analysis of snapper meatballs. The results showed that all fish meatball treatments with the addition of seaweed porridge were still preferred by panelists. However, the treatment of adding seaweed porridge by $20 \%$ was the fishball treatment that was most favored by panelists with a taste score of 6.5 (very like), aroma of 7.5 (very like), and suppleness of 4.6 (very chewy). In addition, the addition of $20 \%$ seaweed porridge produced $74.0 \%$ water content, $1.3 \%$ ash content, $1.4 \%$ fat content, and $12.7 \%$ protein content. Meatballs with the addition of seaweed porridge have fulfilled SNI standards 01-7266-2014.

Keywords: Fish Meatballs, E.Cottoni, Organoleptics 


\section{PENDAHULUAN}

Rumput laut merupakan salah satu bahan pangan hasil perikanan yang mengandung serat yang memiliki manfaat bagi tubuh manusia (Rosyidi et al. 2008). Salah satu jenis rumput laut yang mempunyai nilai ekonomis penting yaitu Eucheuma cottonii (KKP, 2013). Rumput laut jenis E. cottonii mengandung serat pangan yang cukup tinggi yaitu $25,05 \%$ dan serat kasar sebesar 5,91\% (Matanjun et al. 2009). Disamping itu, Eucheuma cottonii menggandung karaginan yang dapat dimanfaatkan sebagai bahan pengenyal, pengental, pembentuk tekstur dan stabilisator (Mou et al. 2004). Berdasarkan kandungan yang dimiliki rumput laut, maka rumput laut dapat digunakan sebagai bahan tambahan pada produk perikanan untuk meningkatkan nilai gizi dan memperbaiki tekstur. Salah satunya adalah produk bakso. Bakso merupakan salah satu makanan yang banyak digemari oleh semua golongan umur dalam masyarakat, karena rasanya yang enak dan cara pembuatannya yang mudah (Hartati, 2011). Bakso umumnya dibuat menggunakan bahan dasar daging sapi dengan campuran bahan lainnya seperti tepung tapioka sebagai bahan pengisi, garam, gula, lada, es batu, bawang merah dan bawang putih sebagai bumbu atau bahan tambahan.

Selain bahan dasar daging, bakso juga dapat dibuat menggunakan daging ikan. Pembuatan bakso menggunakan daging ikan merupakan salah satu bentuk diversifikasi olahan ikan saat ini (Lakahena, 2015). Daging ikan yang dipilih untuk membuat bakso adalah ikan yang mempunyai daging berwarna putih, misalnya pada ikan tenggiri, kakap, kerapu, cunang dan lain sebagainya (Oktavianingsih, 2008). Pengolahan bakso menggunakan ikan kakap merupakan salah satu cara alternatif untuk memanfaatkan potensi perikanan yang cukup melimpah di Pulau Sumba NTT. Hal ini disebabkan karena ikan kakap menggandung protein yang tinggi berkisar 16, $61 \%$ (Natsir \& Latifa, 2018).
Pembuatan dasar bakso ikan selalu menggunakan tepung atau pati sebagai bahan pengikat. Tepung tapioka merupakan salah satu bahan pengikat yang digunakan untuk meningkatkan daya ikat air, akan tetapi mempunyai pengaruh yang kecil terhadap emulsifikasi dalam menghasikan kualitas bakso yang baik (Lakahena, 2015). Namun, penggunaan tepung tapioka diatas $50 \%$ dari berat daging menghasilkan bakso dengan kualitas dan mutu yang rendah sehingga mempengaruhi tingkat penerimaan konsumen (Adawyah, 2006). Oleh sebab itu, perlu dilakukan salah satu upaya untuk mengurangi jumlah penggunaan tepung tapioka tanpa menurunkan kualitas dan mutu pada bakso ikan yakni dengan penambahan bubur rumput laut.

Penambahan bubur rumput laut dalam pembuatan bakso ikan dapat memperbaiki kualitas produk karena sifat fungsional rumput laut sebagai emulsifier. Penggunaan rumput laut sebagai bahan tambahan dalam pembuatan bakso ikan dapat meningkatkan nilai gizi dan kandungan serat pada produk bakso (Puspitasari, 2008). Selain itu, Yulianingsih (2005) juga melaporkan bahwa karagenan yang terkandung pada rumput laut berfungsi sebagai stabilisator (pengatur keseimbangan), bahan pengental dan pembentuk gel dalam industri pengolahan makanan. Karagenan mampu memperbaiki tekstur dan kekenyalan gel produk, serta dapat meningkatkan daya mengikat air. Namun, informasi tentang penambahan rumput laut terhadap mutu bakso ikan kakap sampai saat ini belum banyak dilaporkan. Oleh sebab itu, masih perlu dilakukan penelitian tentang penambahan rumput laut (Euchema cottoni) terhadap mutu bakso ikan kakap (Lutjanus bitaeniatus).

\section{BAHAN DAN METODE}

\section{Alat dan Bahan}

Alat yang digunakan untuk pembuatan bakso meliputi pisau, mesin penggiling daging, 
baskom, mixer, panci, dan kompor. Sedangkan bahan yang digunakan yakni rumput laut Eucheuma cottoni, tepung terigu, tepung kanji, telur, bawang putih, garam, dan penyedap rasa.

\section{Tahapan Penelitian}

\section{Persiapan rumput laut Eucheuma cottoni,}

Rumput laut Eucheuma cottoni pertama kali dicuci dan dibilas dengan air bersih sebelum diolah menjadi bubur rumput laut. Selanjutnya rumput laut yang sudah bersih dihaluskan menggunakan blender hingga halus seperti bubur.

\section{Pembuatan bakso ikan kakap dengan} penambahan rumput laut Eucheuma cottoni

Pembuatan bakso ikan kakap diawali dengan pembuatan filet ikan terlebih dahulu. Filet ikan kakap seberat 400 gram selanjutnya digiling dengan terlebih dahulu daging ikan dipotong-potong kecil setebal 0,5-0,7 cm dengan ditambahkan es batu sebanyak 75 gram (25\% berat daging). Selanjutnya ditambahkan garam 6 gram ( $2 \%$ berat daging) dan bumbu (merica 1 gram, bawang putih 5 gram) ke dalam adonan untuk diblender kembali. Kemudian setelah tercampur merata, ke dalam daging lumat tersebut ditambahkan sedikit demi sedikit tepung tapioka 45 gram (15\% berat daging) sambil diaduk dan dilumatkan hingga diperoleh adonan yang homogeny (Puspita, 2008). Selanjutnya ditambahkan rumput laut sebanyak: $0 \%$; $20 \%$; $40 \%$; dan $60 \%$ dari total berat adonan ke dalam adonan dan diaduk hingga merata. Adonan yang telah homogen dicetak menjadi bola-bola bakso yang siap direbus. Bola-bola bakso direbus dalam air mendidih selama 10-15 menit hingga matang (Wibowo, 2006). Pembuatan bakso ikan kakap dapat dilihat pada Gambar 1.

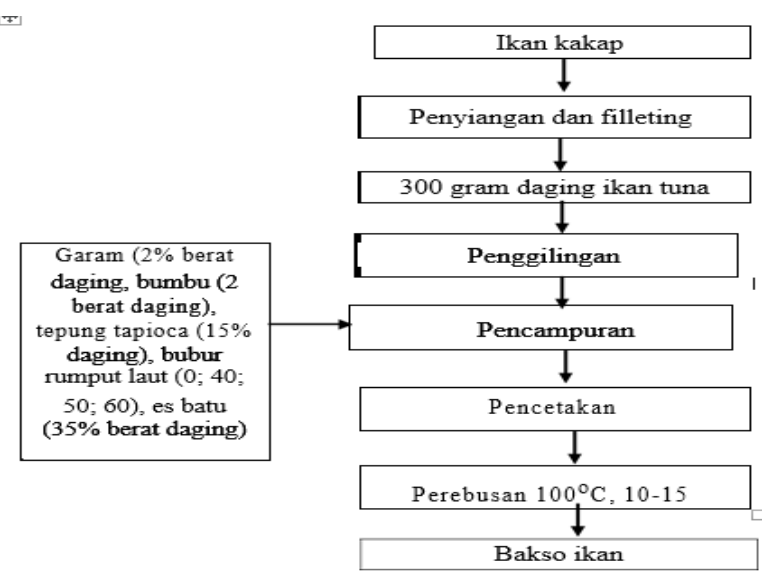

Gambar 1. Diagram Alur Pembuatan Bakso Ikan Kakap (Lutjanus bitaeniatus)

\section{Rancangan Percobaan}

Rancangan percobaan yang digunakan adalah Rancangan Acak Lengkap (RAL) dengan 4 perlakuan penambahan bubur rumput laut yaitu 0 , $20 \%, 40 \%, 60 \%$ dan 3 kali ulangan.

\section{Analisis Data}

Bakso ikan yang dihasilkan pada setiap perlakuan dilakukan uji organoleptik (Rasa, aroma, dan kekenyalan) dengan menggunakan kuiosioner yang memiliki skor dengan skala 1-7 dimana 1 (sangat tidak suka), 2 (tidak suka), 3 (agak tidak suka), 4 (agak suka), 5 (suka), 6 (sangat suka), dan 7 (amat suka). Uji organoleptik dilakukan oleh panelis yang terlatih dengan jumlah 20 orang panelis. Selanjutnya, kemudian dilakukan analisis proksimat pada bakso seperti kadar air, kadar abu, kadar lemak, kadar protein pada masing-masing perlakuan. Data yang diperoleh dilakukan uji normalitas dan uji homogenitas. Selanjutnya, data dianalisis menggunakan sidik ragam. Jika terdapat beda nyata maka dilanjutkan dengan uji Duncan dengan tingkat kepercayaan 95\%.

\section{HASIL DAN PEMBAHASAN}

\section{Uji Organoleptik}

\section{Rasa}

Cita rasa merupakan salah satu faktor sifat sensori yang paling sangat penting dalam 
penerimaan suatu produk pangan. Hasil uji organoleptik terhadap rasa bakso ikan ikan yang ditambah dengan rumput laut euchema cottoni dapat dilihat pada Gambar 2.

Berdasarkan Gambar 2 bahwa penilaian panelis terhadap rasa bakso ikan dengan penambahan rumput laut euchema cottoni yakni berkisar 4.6-6.5 (suka dan sangat suka) yang artinya rasa dari seluruh perlakuan masih dapat diterima oleh panelis. Nilai panelis tertinggi terhadap rasa bakso ikan dengan penambahan rumput laut yakni terdapat pada penambahan konsentrasi rumput laut Euchema cottoni sebanyak $20 \%$ sebesar 6,5 $\%$ dengan rasa yang sangat gurih dan memiliki rasa khas ikan. Sedangkan nilai panelis terendah terdapat pada perlakukan tanpa penambahan konsentrasi rumput laut $0 \%$ (kontrol) dengan rasa bakso ikannya yang cukup kuat. Penambahan bubur rumput laut pada bakso ikan kakap memberikan pengaruh yang nyata $(p>0,05)$ terhadap rasa bakso ikan kakap. Hal ini sejalan dengan penelitian Ririsanti et al., (2011) melaporkan bahwa penambahan bubur rumput laut Euchema cottoni memberikan pengaruh yang nyata terhadap pempek ikan lele. Hal ini disebabkan karena rasa bakso ikan sangat dipengaruhi oleh kandungan protein, lemak dan karbohidrat serta kandungan gizi dari bubur rumput laut yang terkandung dalam bakso ikan kakap. Hal ini didukung oleh penelitian Priangga et al., (2015) yang melaporkan bahwa cita rasa makanan sangat dipengaruhi oleh kandungan protein, lemak, dan karbohidrat yang menyusunnya.

\section{Aroma}

Aroma adalah rasa dan bau yang sangat subyektif serta sulit diukur, karena setiap orang mempunyai sensitifitas dan kesukaan yang berbeda.Meskipun mereka dapat mendeteksi, tetapi setiap individu memiliki kesukaan yang berlainan (Meilgaard et al., 2000). Aroma pada produk pangan sebagian besar berasal dari bahan baku yang digunakan dan bumbubumbu yang ditambahkan pada saat membuat bakso ikan kakap. Bau yang diterima oleh indera penciuman dan otak merupakan perpaduan empat bau utama yakni harum, asam, tengik, dan hangus (Winarno,1997). Hasil uji organoleptik terhadap rasa bakso ikan ikan yang ditambah dengan rumput laut Euchema cottoni tersaji pada Gambar 3.

Berdasarkan penilaian panelis terhadap aroma bakso ikan kakap dengan penambahan bubur rumput laut Euchema cottoni sekitar 6.97.5 (sangat suka) sehingga dapat disukai oleh semua panelis. Nilai panelis tertinggi terhadap aroma bakso ikan yakni terdapat pada perlakuan tanpa penambahan bubur rumput lau $0 \%$ (kontrol) sedangkan nilai terendah terhadap aroma bakso ikan pada perlakuan penambahan bubur rumput laut sebesar $60 \%$. Penambahan bubur rumput laut pada bakso ikan kakap tidak memberikan pengaruh yang nyata $(p>0,05)$ terhadap aroma bakso. Hal ini diduga karena bubur rumput laut yang ditambahkan ke dalam bakso mempunyai aroma yang netral dan tidak berbau sehingga penilaian panelis terhadap aroma bakso ikan kakap sama terhadap perlakukan lainnya. Selain itu, penambahan bumbu seperti bawang putih dan penyedap rasa yang diberikan pada setiap perlakuan sama sehingga memiliki aroma bakso ikan yang sama pula pada tiap perlakuan. Hal ini sejalan dengan hasil penelitian Firahmi et al. (2015) bahwa formulasi bumbu, dan bahan pengisi dalam pembuatan bakso sangat mempengaruhi terhadap aroma bakso yang dihasilkan.

\section{Kekenyalan}

Kekenyalan adalah kemampuan bahan pangan yang ditekan kembali ke kondisi awal setelah beban tekanan. Hasil uji organoleptik terhadap kekenyalan bakso ikan ikan yang ditambah dengan rumput laut Euchema cottoni tersaji pada Gambar 4.

Berdasarkan penilaian panelis terhadap aroma bakso ikan kakap dengan penambahan bubur rumput laut Euchema cottoni sekitar 3.44.6 (agak kenyal dan sangat kenyal) sehingga dapat disukai oleh semua panelis. Penambahan bubur rumput laut pada bakso ikan kakap memberikan pengaruh yang nyata $(p>0,05)$ terhadap kekenyalan bakso. Penilaian panelis tertinggi terhadap 
kekenyalan bakso yang sangat kenyal terdapat pada perlakuan dengan penambahan bubur rumput laut sebesar $20 \%$ sedangkan perlakuan tanpa penambahan rumput laut (kontrol) lebih rendah dibandingkan dengan perlakuan penambahan rumput laut. Hal ini disebabkan karena adanya penambahan bubur rumput laut di dalam bakso sehingga bakso menjadi kenyal. Bubur rumput laut yang tercampur di dalam bakso mampu meningkatkan daya serap air sehingga bakso menjadi kenyal. Hal ini sejalan dengan penelitian Rahmatina (2010) yang melaporkan bahwa kekenyalan bakso sangat dipengaruhi oleh kondisi daging dan kemampuan menyerap air.

\subsection{Analisis Kimia}

Hasil analisis karakteristik kimia bakso ikan kakap dengan konsentrasi penambahan rumput laut Euchema cottoni yang berbeda meliputi kadar air, kadar abu, kadar protein, dan kadar lemak tersaji pada Tabel 1 (Lampiran).

\section{Kadar Air}

Kadar air merupakan salah satu karakteristik yang sangat penting dalam sebuah pangan. Kadar air adalah jumlah air yang terkandung dalam bahan yang dinyatakan dalam bentuk persen (Nugroho et al. 2014). Hasil pengukuran kadar air memberikan pengaruh yang nyata. Berdasarkan pada Tabel 1 terlihat bahwa kadar air pada bakso ikan kakap mengalami peningkatan seiring dengan meningkatnya penambahan konsentrasi bubur rumput laut Euchema cottoni. Hal ini disebabkan karena adanya penambahan rumput laut Euchema cottoni yang menggandung kandungan air yang cukup tinggi di dalam bakso ikan. Selanjutnya, rumput laut Euchema cottoni memiliki sifat yang mampu menyerap air sehingga sumbangan air dari rumput laut di dalam bakso meningkat. Hal ini sejalan dengan hasil penelitian Rahmawati et al., (2014) bahwa dengan penambahan rumput laut Euchema cottoni dapat meningkatkan nilai kadar air. Rumput laut memiliki kandungan air yang cukup tinggi sekitar 27,8 \% pada produk nugget (Arnyke et al., 2014).

\section{Kadar Abu}

Kadar abu merupakan salah satu faktor yang menentukan kandungan mineral suatu bahan. Berdasarkan Tabel 1 bahwa hasil analisa kadar abu tanpa penambahan konsentrasi rumput laut (kontrol) lebih besar dibandingkan dengan perlakuan bakso dengan penambahan konsentrasi rumput laut Euchema cottoni. Hasil pengukuran Tabel 2 bahwa penambahan rumput laut meningkatkan nilai kadar abu dalam bakso ikan kakap. Hal ini disebabkan karena adanya pengaruh garam mineral yang terkandung di dalam rumput laut yang ditambahkan dalam formulasi bakso ikan kakap. Hal ini didukung oleh Amaliah et al.,(2016); Maharany et al., (2017) melaporkan bahwa kadar abu sangat dipengaruhi oleh kandungan mineral dan iodium pada rumput laut. Hasil pengukuran kadar abu tertinggi dengan penambahan rumput laut Euchema cottoni terdapat pada perlakuan penambahan rumput laut $60 \%$ sebesar 1,52. Nilai kadar abu bakso ikan menurut SNI 01-7266-2014 yaitu maksimal $2 \%$. Bakso ikan kakap dengan penambahan bubur rumput laut Euchema cottoni memenuhi persyaratan SNI dengan nilai kadar abu masih dibawah $2 \%$.

\section{Kadar Lemak}

Berdasarkan Tabel 1, bahwa hasil analisa kadar lemak bakso ikan kakap dengan penambahan konsentrasi rumput laut lebih kecil bila dibandingkan dengan kadar lemak bakso ikan tanpa penambahan rumput laut (kontrol). Nilai rata-rata kadar lemak dengan penambahan rumput laut pada bakso ikan kakap yakni 1,22-1,43 \%. Penambahan konsentrasi rumput laut di dalam bakso ikan mampu menurunkan nilai kadar lemak. Hal ini disebabkan karena adanya kandungan karaginan yang terkandung dalam Euchema cottoni yang berfungsi sebagai water binding (pengikat air) sehingga semakin tinggi karaginan makan semakin banyak kandungan lemak yangb terlepas. Hal ini didukung oleh penelitian Widodo (2008) melaporkan bahwa semakin meningkat karaginan maka semakin banyak pula lemak yang terlepas dan 
menyebabkan stabilitas emulsi bahan semakin rendah. Hasil penelitian Amaliah et al. (2016) juga melaporkan bahwa penambahan rumput laut $K$. alvarezii dapat menurunkan kadar lemak pada bakso ikan payus. Nilai kadar lemak bakso ikan menurut SNI 01-7266-2014 yaitu maksimal $2 \%$. Bakso ikan kakap dengan penambahan bubur rumput laut Euchema cottoni memenuhi persyaratan SNI dengan nilai kadar abu masih dibawah $2 \%$.

\section{Kadar Protein}

Berdasarkan Tabel 1, bahwa hasil analisa kadar protein bakso ikan kakap dengan penambahan konsentrasi rumput laut lebih besar bila dibandingkan dengan kadar lemak bakso ikan tanpa penambahan rumput laut (kontrol). Nilai rata-rata kadar protein dengan penambahan rumput laut pada bakso ikan kakap yakni 11,76-12,78 \%. Penambahan konsentrasi rumput laut di dalam bakso ikan mampu meningkatkan nilai kadar protein. Hal ini disebabkan karena Euchema cottoni memiliki kandungan karaginan yang jumlah gugus sulfatnya banyak. Banyaknya gugus sulfat dalam karaginan menyebabkan kemampuan untuk menetralisir muatan protein semakin dan meningkat. Selanjutnya, kandungan karaginan pada Euchema cottoni memiliki sifat sebagai water binding (pengikat air) sehingga dapat menimalisir terjadinya kehilangan protein yang terikat pada karaginan. Hal ini didukung oleh Thamrin dan Sadimantara (2014) melaporkan bahwa pengaruh karaginan terhadap protein ditentukan oleh jumlah gugus sulfat yang terdapat pada karaginan. Selanjutnya hasil penelitian Trisnawati dan Nisa (2015) melaporkan bahwa karaginan memiliki sifat mengikat dan menerangkap air dalam matriks gel sehingga dapat menimalisir kehilangan protein larut dalam air. Hasil analisis kadar protein tidak memberikan pengaruh yang nyata dengan semakin meningkatnya penambahan konsentrasi rumput laut yang digunakan pada bakso ikan kakap. Nilai kadar protein bakso ikan menurut SNI 01-7266-2014 yaitu minimum $7 \%$. Bakso ikan kakap dengan penambahan bubur rumput laut memenuhi persyaratan SNI dengan rata-rata nilai kadar protein diatas $7 \%$.

\section{SIMPULAN}

Bakso ikan kakap dengan penambahan bubur rumput laut memberikan pengaruh yang signifikan terhadap rasa, keempukan dan kandungan kimiawi. Penambahan bubur rumput laut E. Cottoni sebanyak $20 \%$ merupakan konsentrasi terbaik yang paling disukai oleh panelis.

\section{DAFTAR PUSTAKA}

Amaliah S, Munandar A, Haryati S. 2016. Pengaruh Penambahan Bubur Rumput Laut (Kappaphycus alvarezii) Terhadap Karakteristik Bakso Ikan Payus (Elops hawaiensis). Jurnal Perikanan dan Kelautan 6(1): 40-50.

Arnyke EV, Rosyidi D, Radiati LE. 2014. Peningkatan Potensi Pangan Fungsional Naget Daging Kelinci Dengan Subsitusi Wheat Bran, Pollard dan Rumput Laut. Jurnal Ilmu-ilmu Peternakan (24).

Firahmi N, Dharmawati S, Aldrin M. 2015. Sifat Fisik dan Organoleptik Bakso yang dibuat Dari Daging Sapi Dengan Lama Pelayuan Berbeda. Jurnal Alulum Sains dan Teknologi 1(1):39-45.

KKP] Kementerian Kelautan dan Perikanan. 2013. Kelautan dan Perikanan daam Angka 2013. Jakarta (ID): Kementerian Kelautan dan Perikanan. HIm. 18-19.

Matanjun P, Mohamed S, Mustapha NM, Muhammad K. 2009. Nutrient content of tropical edible seaweed, Eucheuma cottonii, Caulerpa lentillifera and Sargassum polycystum. Journal of Applied Phycology. 21: 75-80.

Maharani F, Nurjanah, Suwandi R, Anwar E, Hidayat T. 2017. Kandungan Senyawa Bioaktif Rumput Laut Padina australis dan Euchema cottoni sebagai Bahan Baku Krim Tabir Surya. Jurnal Pengolahan Hasil Perikanan Indonesia 20(1):10-18. 
Agrisaintifika

Jurnal Ilmu-Ilmu Pertanian

Vol. 4, No. 2, 2020

Tarigan, Nurbety. 2020

Meilgard, M., G. V. Civille, dan B. T. Carr. 2000. Sensory evaluation techniques 3rd Ed. CRC Press, Boca Raton.

Nugroho SA, Dewi EN, Romadhon. 2014. Pengaruh Perbedaan Konsentraasi Karagenan Terhadap Mutu Bakso Udang. Jurnal Pengolahan Bioteknologi Hasil Perikanan. 3(4):59-64.

Oktavianingsih Y. 2008. Proses Pengolahan Bakso Ikan Lele Dumbo (Clarias gariepinus) di Desa Bandung Kecamatan Diwet Kabupaten Jombang, Jawa Timur. Skripsi. Universitas Brawijaya. Malang

Priangga DA, TW Agustini, I Wijayanti. 2015. Pengaruh Penambahan Karagenan Sebagai Stabilizer terhadap Karakteristik Otak-otak Ikan Kurisi (Nemipterus nematophorus). Jurnal Pengolahan dan Bioteknologi Hasil Perikanan. 4 (2):1-5

Rahmawati DS, Zuraida I, Hasanah R. 2014. Pemanfaatan Rumput Laut (Eucheuma cottonii) Pada Pengolahan Bakso Ikan. Jurnal IImu Perikanan Tropis 16 (1):2-8.

Rahmatina. 2010. Sifat Fisik dan Organoleptik Bakso Pada Berbagai Rasio Antara Daging Sapi dan Daging Ayam. Skripsi. Fakultas Perikanan dan Kelautan. Institut Pertanian Bogor. Bogor

Ririsanti NN, Evi L, Yudi NI, Rusky IP. 2017. Penambahan Karagenan Terhadap Tingkat Kesukaan Pempek Lele. Jurnal Perikanan dan Kelautan 18 (1):165-173.

Surawan, F. E. 2007. Penggunaan Tepung Terigu, Tepung Beras, Tepung Tapioka dan Tepung Maizena terhadap Tekstur dan Sifat Sensoris Fish Nugget Ikan Tuna. Jurnal Sain Peternakan Indonesia. 2 (2):12-18.

Tamrin, Sadimantara MS. 2014. Kadar Karaginan Terhadap Karasteristik Kimia Pasta Mete. Jurnal Agriplus 2 (24):21-28.

Trisnawati MI, Nisa FC. 2015. Pengaruh Penambahan Konsentrat Protein Daun Kelor Dan Karagenan Terhadap Kualitas Mie Kering Tersubstitusi Mocaf. Jurnal Pangan dan Agroindustri (3):1-8.

Widodo, Setyo A. 2008. Karakteristik Sosis Ikan Kurisi (Nemipiterus nematophorus) 
Agrisaintifika

Jurnal Ilmu-Ilmu Pertanian

Vol. 4, No. 2, 2020

Tarigan, Nurbety. 2020

Lampiran.

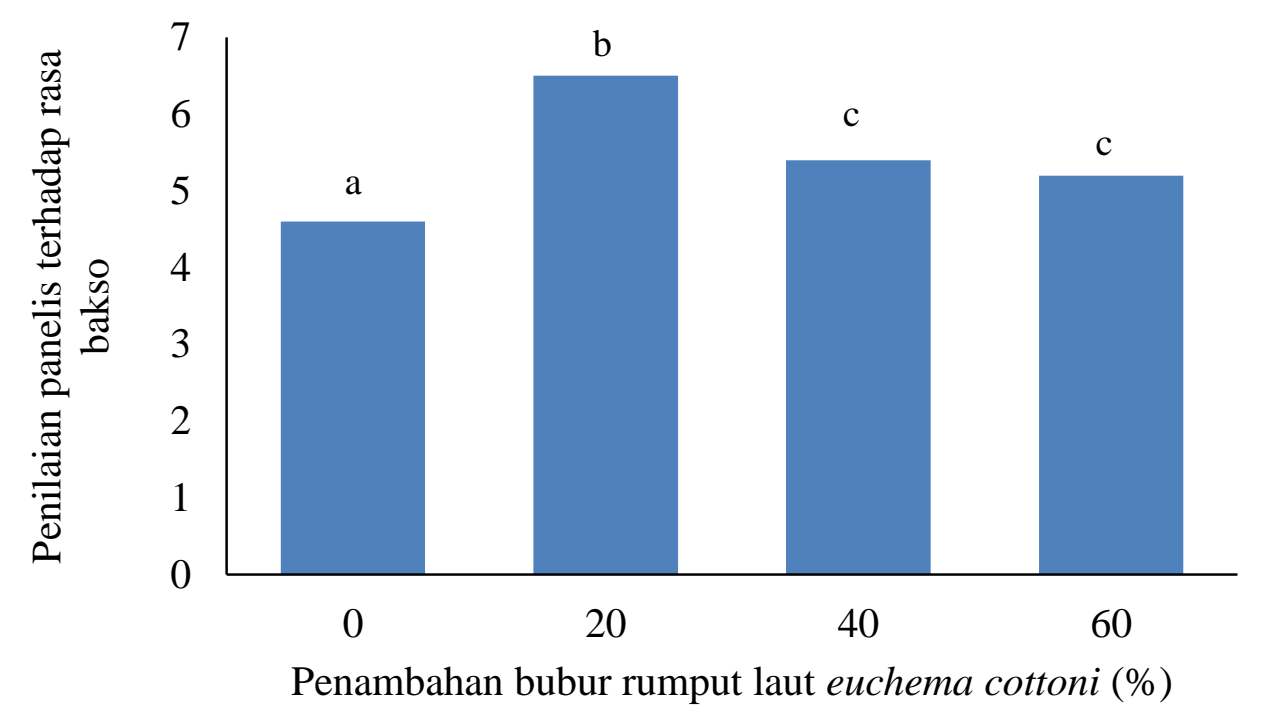

Gambar 2. Penilaian panelis terhadap cita rasa bakso ikan kakap dengan penambahan rumput laut euchema cottoni yang berbeda

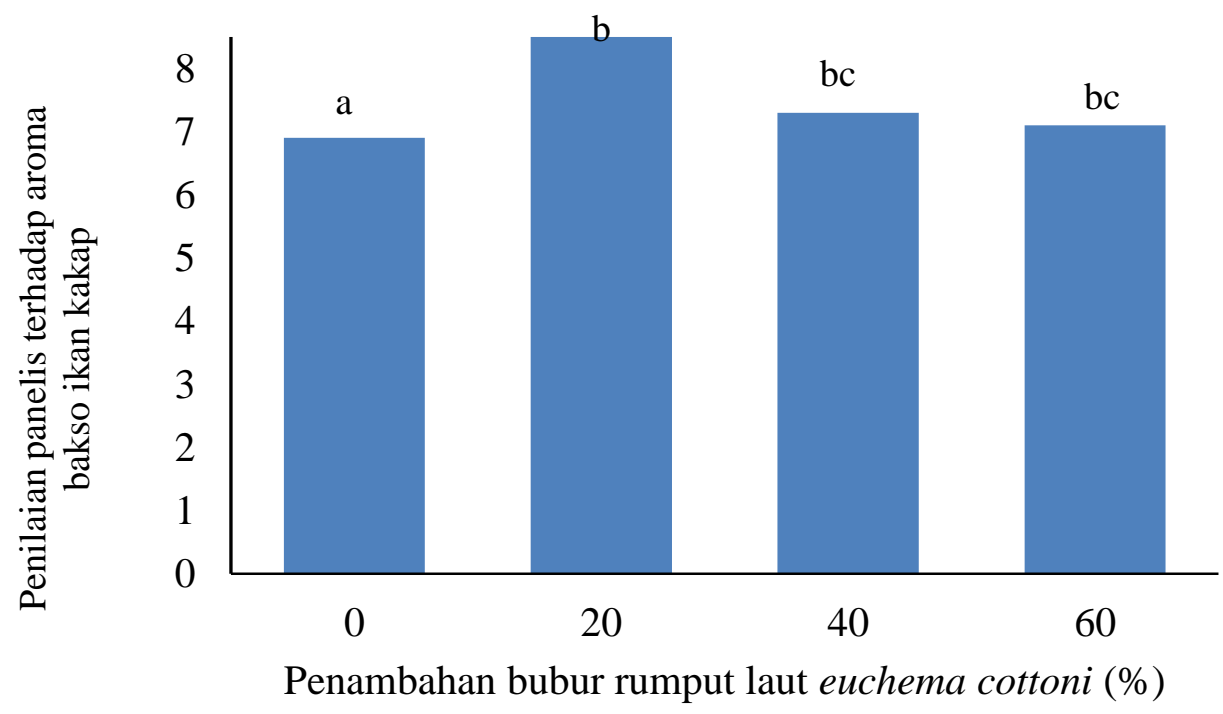

Gambar 3. Penilaian panelis terhadap aroma bakso ikan kakap dengan penambahan rumput laut euchema cottoni yang berbeda 
Agrisaintifika

Jurnal Ilmu-Ilmu Pertanian

Vol. 4, No. 2, 2020

Tarigan, Nurbety. 2020

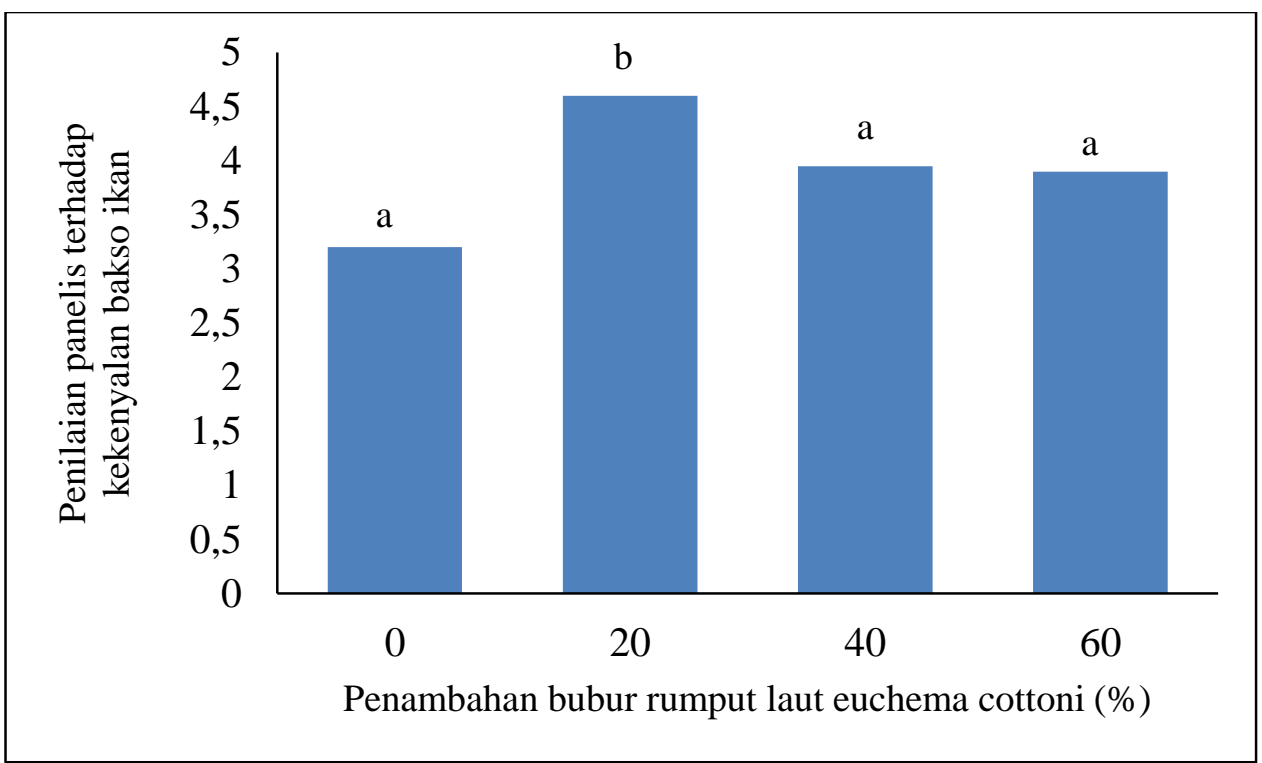

Gambar 4. Penilaian panelis terhadap kekenyalan bakso ikan kakap dengan penambahan rumput laut euchema cottoni yang berbeda

Tabel 1. Nilai rata-rata hasil analisis kimia bakso ikan kakap dengan konsentrasi penambahan rumput laut Euchema cottoni yang berbeda

\begin{tabular}{lllll}
\hline Parameter & \multicolumn{4}{c}{ Konsentrasi Penambahan Rumput Laut Euchema cottoni $(\%)$} \\
\cline { 2 - 5 } & \multicolumn{1}{c}{0} & 20 & 40 & 60 \\
\hline Kadar air & $68,93 \pm 0.57^{\mathrm{a}}$ & $74,08 \pm 0.14^{\mathrm{b}}$ & $77,80 \pm 0.32^{\mathrm{b}}$ & $79,63 \pm 0.18^{\mathrm{c}}$ \\
Kadar abu & $2,17 \pm 0.22^{\mathrm{c}}$ & $1,32 \pm 0.15^{\mathrm{a}}$ & $1,49 \pm 0.45^{\mathrm{b}}$ & $1,52 \pm 0.12^{\mathrm{b}}$ \\
Kadar lemak & $1,72 \pm 0,32^{\mathrm{d}}$ & $1,43 \pm 0,27^{\mathrm{c}}$ & $1,22 \pm 0.41^{\mathrm{a}}$ & $1,30 \pm 0.34^{\mathrm{b}}$ \\
Protein & $8,40 \pm 0,17^{\mathrm{a}}$ & $12,78 \pm 0.23^{\mathrm{b}}$ & $12,24 \pm 0.41^{\mathrm{bc}}$ & $11,76 \pm 0.56^{\mathrm{c}}$ \\
\hline
\end{tabular}

Keterangan: Angka yang diikuti huruf dengan superscript berbeda pada baris yang sama menunjukkan perbedaan yang nyata $(P<0.05)$. 